\title{
Cultural management as a tourism competitiveness factor. A principal component analysis (PCA) for Colombia
}

\section{La gestión cultural como factor de competitividad turística. Un análisis de componentes principales para Colombia}

Daniel Corzo-Arévalo ${ }^{1 *}$, Sebastián García-Méndez ${ }^{2}$ and Juan Camilo Gutiérrez ${ }^{3}$

${ }^{1}$ Research professor at GECAC research group, Corporación Universitaria de Ciencia y Desarrollo -UNICIENCIA. Bucaramanga, Colombia. Código ORCID http://orcid.org/0000-0001-6017-8028 ${ }^{2}$ Research professor at SINERGIA research group, Universidad de Investigación y Desarrollo. Bucaramanga, Colombia. Código ORCID https://orcid.org/0000-0002-6077-0248 ${ }^{3}$ Research professor at SINERGIA research group, Universidad de Investigación y Desarrollo. Bucaramanga, Colombia. Código ORCID https://orcid.org/0000-0003-0386-1706 * Corresponding author: danielcorzoarevalođgmail.com

\section{ABSTRACT}

This article aims to present a comparative analysis of a range of variables from the Regional Tourism Competitiveness Index of Colombia (ICTRC, for its acronym in Spanish), developed by the Centre for Tourism Thinking (CPTUR), inherent to the dimension of Cultural Management in 22 Colombian territories. Principal component analysis was applied to measure the correlation between eight ICTRC variables, which account for the level of cultural management in Colombia. The analysis revealed that the cultural management factors from the ICTRC can be grouped in two wide groups: preexisting factors and factors derived from new strategies. The 22 territories were classified in three clusters: the first one is high performing in both factor types, the second one is high performing in preexisting factors but low performing in factors derived from new strategies, and the third one is high performing in factors derived from new strategies but low performing in preexisting factors. It is concluded that tourism competitiveness in the cultural realm is dynamic. Therefore, the many actors in the tourism sector value chain will have to formulate strategic, tactic and operational actions in the wide range of companies' and destinations' functional areas in order to increase competitiveness in cultural management.

Keywords: tourism competitiveness, cultural management, Colombia, principal component analysis

\section{RESUMEN}

La presente investigación tiene como objetivo realizar un análisis comparativo de las diversas variables del Índice de Competitividad Turística Regional de Colombia (ICTRC) desarrollado por el Centro de Pensamiento Turístico (CPTUR), inherentes a la dimensión de Gestión Cultural en 22 territorios de Colombia. Se aplicó el método del análisis de componentes principales para medir la correlación entre 8 variables seleccionadas del ICTRC, que dan cuenta de la gestión cultural en Colombia. El análisis reveló que las variables de gestión cultural del ICTRC se agrupan en dos amplios grupos: factores preexistentes y factores derivados de nuevas estrategias. Los 22 territorios se clasificaron en tres grupos: el primero, con un alto desempeño en ambos tipos de factores, el segundo con alto desempeño en factores preexistentes, pero bajo en factores derivados de nuevas estrategias, y el tercero con un alto desempeño en factores derivados de nuevas estrategias, pero bajo en factores preexistentes. Se concluye que la competitividad turística de los territorios a nivel cultural es dinámica, por consiguiente, los diferentes actores de la cadena de valor del sector turístico deberán formular acciones estratégicas, tácticas y operativas en las diversas áreas funcionales de las compañías y los destinos para lograr un aumento de la competitividad desde la gestión de la cultura.

Palabras clave: Competitividad turística, gestión cultural, Colombia, componentes principales. 


\section{INTRODUCTION}

Due to the COVID-19 pandemic, tourist destinations face greater difficulties in attracting tourists, giving rise to strong competition in the travel and tourism industry. In this scenario, only the most competitive destinations have a chance to remain relevant and to avoid disappearing. Growing competition is thus generated between destinations to identify new forms of tourist attraction, creating competitive advantages that allow them to differentiate themselves from one another. Destinations are seeking to become popular for international tourists have been forced to make greater efforts in building competitive advantage. In this context, the research question for this article is: is it possible for cultural management to be a source of competitive advantage for tourist destinations? How definitive is cultural management in Colombian tourist destinations?

Previous tourism literature has identified many factors that may contribute to building a destination's competitive advantage (Crouch \& Ritchie, 2012). These include the ability to identify problems problems (Li \& Liu, 2018), the hotel industry's intellectual capital (Li \& Liu, 2018), green initiatives (Singjai, Winata y Kummer, 2018) and service customization (Shoval \& Birenboim, 2019). Cultural factors are seldom studied (Kumar \& Dhir, 2020), despite the fact their understanding is regarded by several recent authors as a potential contributor for tourist destination competitive advantage (Salinas, Serdeira, Martín \& Rodriguez, 2020). It is also argued that, through a more profound understanding of national culture, the government and public policy writers could design more culturally relevant policies to attract international tourists (Salinas et al., 2020).

Thus, the present investigation aims to contribute to the analysis of tourism competitiveness from the perspective of the cultural factor, specifically for 22 Colombian tourist destinations (departments). The structure is as follows: in the following section, the concepts of culture and tourism competitiveness are defined; then, the method and the variables concerning the cultural factor of the 22 Colombian geographical areas (departments) for the 2017-2019 period are presented; thirdly, the results of the principal component analysis, measuring the correlation between the eight variables selected from the Regional Tourism Competitiveness Index of Colombia (ICTRC), estimating destination management in Colombia, are shown. Finally, conclusions obtained in the study are presented.

\section{THEORETICAL FRAMEWORK}

\section{Cultural management}

Culture, regardless of how it is interpreted, is tied to the development process and thereby to competitiveness. Understanding the culture of the destination while interacting with international tourists is one of the important factors to be analysed (Dai, Hein, \& Zhang, 2019; Salinas et al., 2020). Nonetheless, these analyses are mostly limited to the tourist-culture relationship (Nazarian, Atkinson \& Foroudi, 2017). Hence, many tourist destinations do not reach the desired level of competitiveness. This may result in a lower international tourist visit rate, which suggests that destinations are struggling to achieve a competitive advantage (Salinas et al., 2020).

Academics have argued that there is a consensus on the notion that destination competitiveness is deeply affected by their culture (Clara, Simon, Noelia, \& Barbara, 2019; Goffi, Cucculelli, \& Masiero, 2019). Although current literature has improved our comprehension of the relationship between national culture and tourism, it is not yet clear whether national culture helps countries to become popular tourist destinations and, if so, how. This research gap poses several problems for the realization of the tourism industry's growth potential, such as the lack of tourism policies for governments, policy writers and tourism management organizations, all of whom depend on the tourism industry. The lack of understanding as to why and how a destinations' culture is essential for its competitiveness poses an important challenge for policy writers when designing effective tourism policies for attracting tourists. Therefore, a clearer understanding of national culture may help to improve a country's destination competitiveness (Kumar \& Dhir, 2020).

\section{Tourism competitiveness}

The tourism boom of the past decades has motivated governments to focus on boosting their countries' and destinations' tourism competitiveness, considering them as a catalyst for human development (Corzo \& García, 2020) and thus driving their sociocultural and economic conditions (Das \& Dirienzo, 2009; Das \& Dirienzo, 2012; Croes \& Kubickova, 2013; Mihalic \& Aramberri, 2015; Azzopardi \& Nash, 2017; Nazmfar, Eshghei, Alavi \& Pourmoradian, 
2019; Wang \& Liu, 2020). Cultural management allows destinations to increase their capacity to develop resources through memorable tourist experiences, impacting on the quality of life of the destination's local communities (Kubickova \& Lee, 2018; Croes, Ridderstaat \& Shapoval, 2020), minimizing environmental damage and growing the cultural and social resources that the destination possesses (Corzo, 2016).

Jiménez \& Aquino (2012) propose a tourism competitiveness model that allows to analyze a destination's competitiveness through the successive study of groups of factors with common effects on the tourist-destination relationship at different times, as well as the end results of such relationship in terms of tourist satisfaction, environmental care, equity and economic efficiency. Unlike other models that only consider resources, activities and processes, Jiménez \& Aquino's (2012) model places a stronger weight on the results of tourist activity, the responsible use of natural and cultural resources and the socioeconomic effects it generates.

The model discards the implicit and commonly accepted premise that all factors have a similar importance for the destination. This is to reduce the risk of rendering general average results, which are often far from reality, since each factor, alone and collectively, has a different effect on tourist destination competitiveness in intensity and time.

Figure 1. Tourist destination competitiveness model

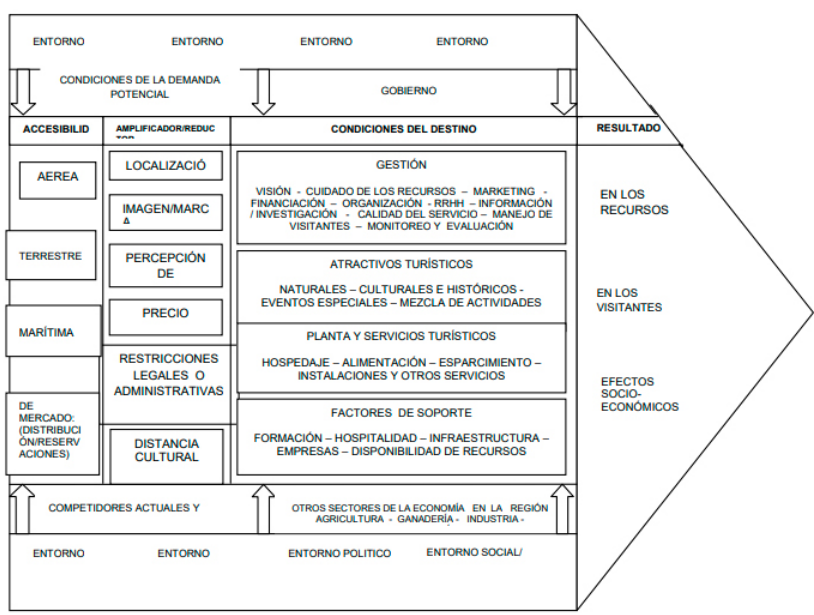

Source: (Jiménez \& Aquino, 2012)
- Accessibility: tourism is enjoyed in situ. Therefore, it requires the tourist to travel and the existence of transportation means for that end. It is divided in four types: air, ground, sea and market (information and distribution).

- Amplifiers or reductors: they contribute to encouraging or discouraging the tourist in their decision to visit the destination. The following factors are considered: geographical location, perception of security, marketing efforts, image and positioning, price and cultural distance (related to language, religion, politics).

- Destination and management conditions: the goal of tourist destination management is to increase its competitive advantages while keeping its comparative advantage. In this case, the role of public managers is to create a competitive climate that allows companies to compete in favorable and equal conditions.

- Triangle of results: results are fundamentally valued with regard to three elements: the visitor, the resources and the socioeconomic benefits for the actors involved in the tourist activity.

- General and specific environment forces: tourist destinations can be considered open systems, since they are in permanent exchange with their environment and cannot be subtracted from it.

\section{METHOD}

Focus and type of study: The present study is descriptive, following the quantitaitve paradigm.

Population and sample: The population and sample were 22 geographical areas (departments) from the Regional Tourism Competitiveness Index of Colombia (ICTRC), developed by the Colombian Centre for Tourism Thinking (CPTUR) in the 2017-2019 period (CPTUR, 2019), presented in the following table: 
Table 1. Geographical areas studied

\begin{tabular}{|c|c|c|c|}
\hline Antioquia & Caquetá & Huila & Risaralda \\
\hline Atlántico & Casanare & Magdalena & Santander \\
\hline Bogotá D.C. & Cauca & Meta & Tolima \\
\hline Bolívar & Cesar & Nariño & $\begin{array}{c}\text { Valle del } \\
\text { Cauca }\end{array}$ \\
\hline Boyacá & Córdoba & $\begin{array}{l}\text { Norte de } \\
\text { Santander }\end{array}$ & \\
\hline Caldas & Cundinamarca & Quindío & \\
\hline
\end{tabular}

Source: The authors

Data analysis: A descriptive analysis was initially performed and then the conglomerate analysis method, from multivariate statistics, was applied (Pérez, Peral, González, Casas, Lozano, García, \& Fernández, 2009). Table 2 shows the variables assigned to the cultural factor in the ICTRC, which were used in this process.

Tabla 2. Variables for the cultural factor in the ICTRC

\begin{tabular}{|l|c|}
\hline \multicolumn{1}{|c|}{ VARIABLE NAME } & CODE \\
\hline Inventory of cultural patrimony & CUL1 \\
\hline Supply of cultural tourism products & CUL8 \\
\hline $\begin{array}{l}\text { Cultural attractions declared as national } \\
\text { goods of cultural interest }\end{array}$ & CUL9 \\
\hline $\begin{array}{l}\text { Cultural attractions declared as world } \\
\text { heritage sites }\end{array}$ & CUL10 \\
\hline Supply of culinary tourism products & CUL12 \\
\hline $\begin{array}{l}\text { Events for the preservation and promotion } \\
\text { of traditional cuisine }\end{array}$ & CUL13 \\
\hline Technical design of cultural products & CUL14 \\
\hline Traditional festivities and events & CUL16 \\
\hline
\end{tabular}

Source: The authors

\section{RESULTS AND DISCUSSION}

\section{Conglomerate analysis}

Cluster or conglomerate analysis is a multivariate statistical technique that was applied to group departments, seeking to maximize the homogeneity within each cluster and the differences between clusters. Squared Euclidian distance was used as an association measure or hierarchical cluster method. The Ward method or Ward aggregation criterion was used as a clustering technique (Eszergár-Kiss \& Caesar, 2017).

The dendogram generated by the SPSS software allows to identify the groups that result in the least increment in the sum of distances within each conglomerate, obtaining four clusters. Table 3 shows the results of the principal component analysis, which identifies the differences between each group (Jafarzadegan, Safi-Esfahani, \& Beheshti, 2019).

Table 3. Rotated component matrix

\begin{tabular}{|l|l|c|c|}
\hline FACTOR & & $\mathbf{1}$ & $\mathbf{2}$ \\
\hline $\begin{array}{l}\text { Technical design of cultural } \\
\text { products }\end{array}$ & CUL14 & 0,734 & 0,202 \\
\hline $\begin{array}{l}\text { Supply of culinary tourism } \\
\text { products }\end{array}$ & CUL12 & 0,716 & $-0,292$ \\
\hline $\begin{array}{l}\text { Supply of cultural tourism } \\
\text { products }\end{array}$ & CUL8 & 0,685 & 0,034 \\
\hline $\begin{array}{l}\text { Events for the preservation } \\
\text { and promotion of traditional } \\
\text { cuisine }\end{array}$ & CUL13 & 0,554 & 0,402 \\
\hline $\begin{array}{l}\text { Inventory of cultural } \\
\text { patrimony }\end{array}$ & CUL1 & 0,401 & $-0,709$ \\
\hline $\begin{array}{l}\text { Cultural attractions } \\
\text { declared as world heritage } \\
\text { sites }\end{array}$ & CUL10 & 0,121 & 0,535 \\
\hline $\begin{array}{l}\text { Traditional festivities and } \\
\text { events }\end{array}$ & CUL16 & 0,063 & 0,519 \\
\hline $\begin{array}{l}\text { Cultural attractions } \\
\text { declared as national goods } \\
\text { of cultural interest }\end{array}$ & CUL9 & 0,487 & 0,518 \\
\hline
\end{tabular}

Source: The authors

The principal component analysis reveals that the variables are grouped in two relevant aspects. The first one is named preexisting or traditional factors and the second one is called factors derived from new strategies. The dispersion diagram shown in Figure 2 was based on these two categories. 
Figure 2. Dispersion diagram of cluster groups

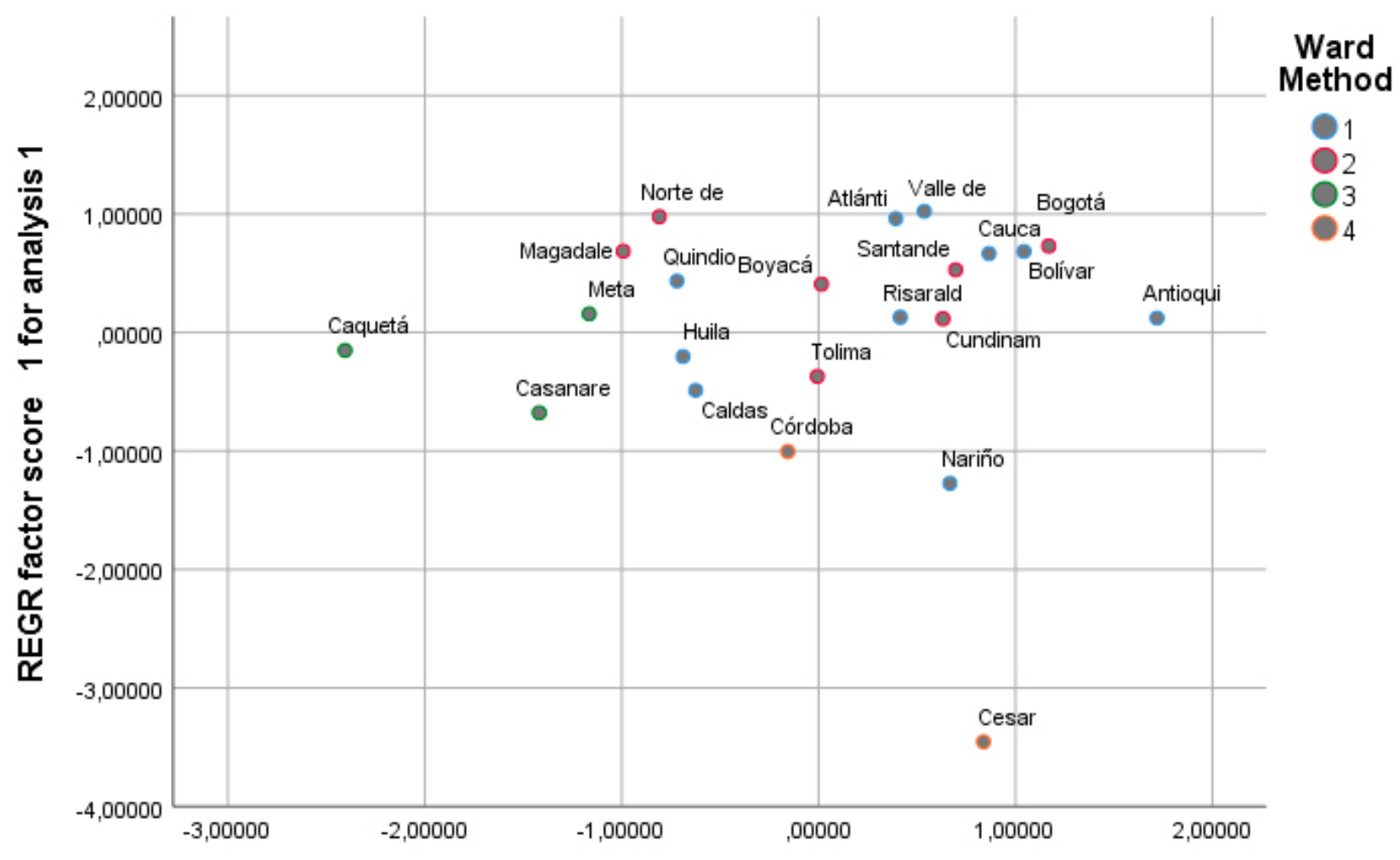

REGR factor score 2 for analysis 1

Source: The authors, based on SPPS V. 25 output

The dispersion diagram shows that clusters 1 and 2 are not markedly different, except for some borderline data points such as the Antioquia department, which has the greatest response tendency with respect to the factors derived from new strategies, followed by Bogotá D.C., though the latter has a better score in the preexisting or traditional factors. This information coincides with the report from the ICTRC survey, which mentions that "the first seven positions are led by the same destinations: Bogotá D.C. and the departments of Bolívar, Valle del Cauca, Antioquia, Risaralda, Quindío and Atlántico". The coherence of the dispersion diagram can thus be verified with the general results from the ICTR report.

Two particular cases are analyzed. The first one is cluster 3 , comprised by the departments of Caquetá, Casanare and Meta, which score around the average of the preexisting or traditional factors, yet are low on the factors derived from new strategies. This is a relevant finding, as it shows that territorial entities are oriented towards putting more effort into factors such as the technical design of cultural products, the supply of culinary and cultural tourism products and events for the preservation and promotion of traditional cuisine. This can also be seen in the department of Nariño, which, despite not belonging to that cluster, shows the lowest response for cluster 1.

Furthermore, cluster 4, comprised by Córdoba and César, can also be studied. They are weak with respect to preexisting or traditional factors. However, when it comes to cultural patrimony inventory, cultural attractions declared world heritage sites, traditional festivities and events and cultural attractions declared as national goods of cultural interest, they show good performance. Hence, territorial entities managing these destinations could strengthen their weak aspects in order to maximize their competitiveness. 
Figure 3. Dendograms 2017 to 2019

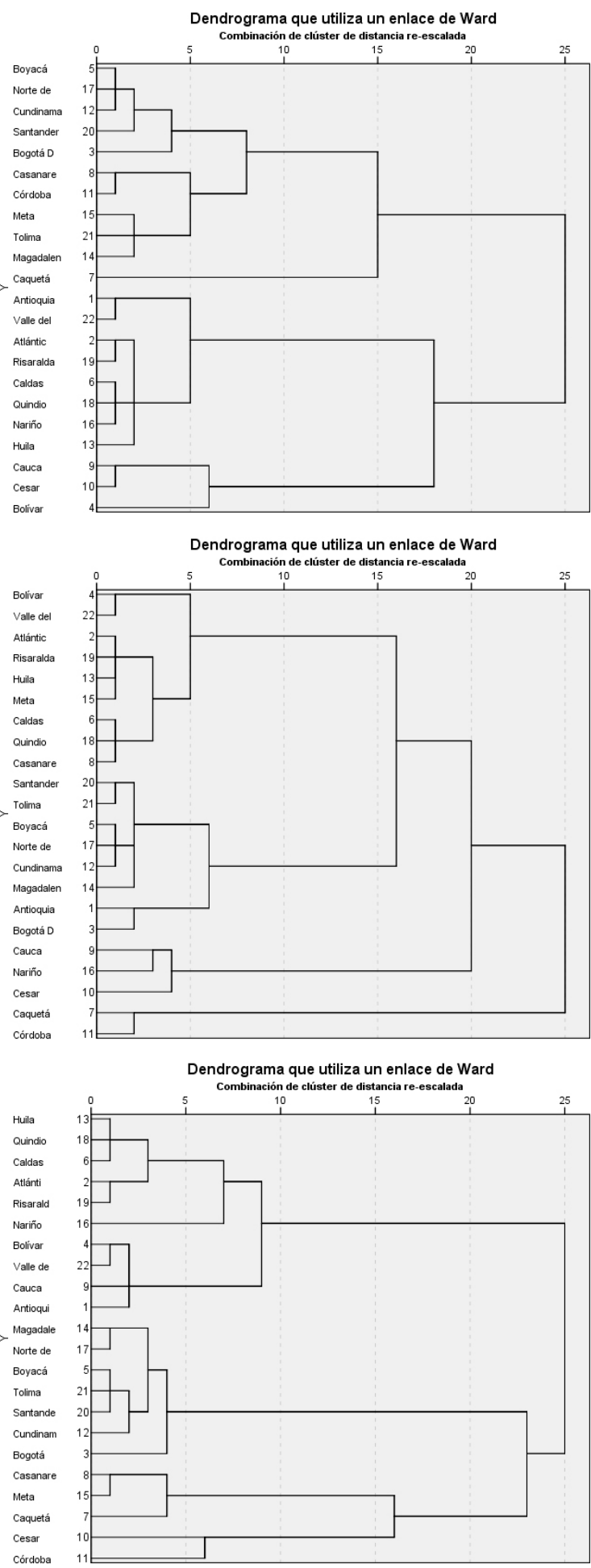

Source: The authors, based on SPPS V. 25 output
The only difference between clusters 1 and 2 is that cluster 2 tends to value an average of the two classes of factors, while cluster 1 orbits around extreme scores, as is the case of Antioquia and Nariño.

Having presented this, the clusters for the 2017 and 2018 surveys (Figure 3 ) were analyzed, in order to compare extreme data and to identify the departments that might have improved or worsened their situation over time.

Among the positive findings of the analysis, the Bolivar department can be identified, which in 2017 was in cluster 3 , showing a weakness in the factors derived from new strategies, but then improves in 2018 and 2019, entering the clusters with an average or above average performance in the country. The Cauca department also presents an improvement in 2019, after performing low in both factor groups. Lastly, the Nariño department, which in 2018 was low on the preexisting or traditional factors, showed some increase in 2019-however, the improvement was not satisfactory.

With regard to the negative results, the Meta and Córdoba departments entered the weak clusters in 2019, the former in cluster 3 and the latter in cluster 4 , with their respective weakness. The evolution shown by each department between all clusters is presented in Table 4 .

Table 4. Evolution by cluster

\begin{tabular}{llll}
\hline & $\mathbf{2 0 1 7}$ & $\mathbf{2 0 1 7}$ & $\mathbf{2 0 1 7}$ \\
\hline Antioquia & 1 & 1 & 1 \\
\hline Atlántico & 1 & 1 & 1 \\
\hline Bogotá D.C. & 2 & 2 & 2 \\
\hline Bolívar & 3 & 3 & 3 \\
\hline Boyacá & 2 & 2 & 2 \\
\hline Caldas & 1 & 1 & 1 \\
\hline Caquetá & 4 & 4 & 4 \\
\hline Casanare & 2 & 2 & 2 \\
\hline Cauca & 3 & 3 & 3 \\
\hline Cesar & 3 & 3 & 3 \\
\hline Córdoba & 2 & 2 & 2 \\
\hline Cundinamarca & 2 & 2 & 2 \\
\hline Huila & 1 & 1 & 1 \\
\hline Magadalena & 2 & 2 & 2 \\
\hline Meta & 2 & 2 & 2 \\
\hline Nariño & 1 & 1 & 1 \\
\hline Norte de Santander & 2 & 2 & 2 \\
\hline Quindio & 1 & 1 & 1 \\
\hline Risaralda & 1 & 1 & 1 \\
\hline Santander & 2 & 2 & 2 \\
\hline Tolima & 2 & 2 & 2 \\
\hline Valle del Cauca & 1 & 1 & 1 \\
\hline Sour & & &
\end{tabular}

Source: The authors 


\section{CONCLUSIONS}

Competition between destinations is currently growing, in a quest for identifying new ways of attracting tourists through a competitive advantage that allows them to differentiate themselves from one another. Cultural management can be a determining factor for tourism competitiveness and hence for increasing tourist visits. Therefore, gaining a deep understanding of national culture will allow governments and tourism policy writers to design more relevant public policies for attracting international tourists.

Although culture, regardless of how it is interpreted, is tied to the development process, and therefore to competitiveness, it is not yet clear whether a destination's culture helps countries to become popular tourist destinations, and how. The lack of understanding about why and how the culture of a destination is essential for its competitiveness poses a challenge for those responsible for formulating policies for attracting tourists. A deeper understanding of national culture can therefore help improve the competitiveness of a destination in a country.

Tourism competitiveness is a complex construct, amply influenced by public and private agents (García, Álvarez, \& Peñuela, 2020). For that reason, improvements in cultural aspects should contemplate the interests and expectations of local actors in the influence zones, with the intention of formulating, implementing and validating strategies based on a situational analysis of the territory. In other words, the destinations of a country may be highly homogeneous or heterogenous, but they should be analyzed within their singularity in order to strive for the betterment of the quality of life of the local people and macroeconomic indicators.

Tourism competitiveness of the territories at the cultural level is dynamic, which implies that the different actors of the tourism sector value chain will have to devise strategic, tactic and operational actions for the many functional areas of a company, with the aim of guaranteeing excellent levels of customer service. This can be converted into revisit intentions on the tourists' part and into indicators oriented towards market survival. The latter is a complex product of the information available and the customer needs in the target market.

\section{REFERENCES}

Azzopardi, E., \& Nash, R. (2017). A Review of Crouch and Ritchie's, Heath's, and Dwyer and Kim's Models of Tourism Competitiveness. Tourism analysis, 22(2), 247-254. https://doi.org/10.3727/10835421 7X14888192562483

\section{Centro de pensamiento turístico de Colombia - CPTUR.} (2019). Índice de Competitividad Turística Regional de Colombia - ICTRC 2019. Bogotá. Cotelco- Unicafama

Clara, R., Simon, D., Noelia, G., \& Barbara, A. (2019). Critical elements in accessible tourism for destination competitiveness and comparison: Principal component analysis from Oceania and South America. Tourism Management, 75 (2019), pp. 169-185. https:// doi.org/10.1016/j.tourman.2019.04.012

Corzo, D. (2016). Valoración del grado de competitividad del sector turístico en la ciudad de Bucaramanga. Aplicación del sistema de indicadores definido por el Ministerio de Comercio, Industria y Turismo. Universidad Autónoma de Bucaramanga. https://doi. org/10.13140/RG.2.2.22349.05605

Corzo, D., \& Garcia, S. (2020). La gestión de departamentos y destinos turísticos de Colombia según el Índice de Competitividad Turística Regional (ICTRC). Revista Internacional de Turismo, Empresa y Territorio.

Croes, R., Ridderstaat, J., \& Shapoval, V. (2020). Extending tourism competitiveness to human development. Annals of Tourism Research, 80, 102825. https://doi. org/10.1016/j.annals.2019.102825

Croes, R., \& Kubickova, M. (2013). From potential to ability to compete: Towards a performance-based tourism competitiveness index. Journal of Destination Marketing \& Management, 2(3), 146-154. https://doi. org/10.1016/j.jdmm.2013.07.002

Crouch, G. I., \& Ritchie, J. R. (2012). Competitiveness and tourism. Edward Elgar Publishing. https://econpapers. repec.org/bookchap/elgeebook/14266.htm

Dai, T., Hein, C., \& Zhang, T. (2019) Understanding how 
Amsterdam city tourism marketing addresses cruise tourists' motivations regarding culture. Tourism Management Perspectives, 29 (2019), pp. 157-165. https:// doi.org/10.1016/j.tmp.2018.12.001

Das, J., \& Dirienzo, C. E. (2012). Tourism competitiveness and the role of fractionalization. International Journal of Tourism Research, 14(3), 285-297. https://doi. org/10.1002/jtr.866

Das, J., \& DiRienzo, C. E. (2009). Global tourism competitiveness and freedom of the press: A nonlinear relationship. Journal of Travel Research, 47(4), 470-479. https://doi.org/10.1177/0047287508326535

De Souza, J., Mendes-Filho, L., Buhalis, D. (2019). Evaluating the effectiveness of tourist advertising to improve the competitiveness of destinations. SAGE Journals Tourism Economics, pp-10001-1020. https://doi. org/10.1177/1354816619846748

Eszergár-Kiss, D., \& Caesar, B. (2017). Definition of user groups applying Ward's method. Transportation Research Procedia, 22(2016), 25-34. https://doi.org/10.1016/j.trpro.2017.03.004.

García-Méndez, S., Álvarez-Parra, L. M. \& Peñuela-Garcés, L. T. (2020). Capítulo 17. Diseño de un plan estratégico de turismo en el municipio de Guadalupe (Santander). Economía Solidaria, 241.

Goffi, G., Cucculelli, M., Masiero, L. (2019). Fostering tourism destination competitiveness in developing countries: The role of sustainability. Journal of Cleaner Production, 209, pp. 101-115. https://doi.org/10.1016/j. jclepro.2018.10.208

Jafarzadegan, M., Safi-Esfahani, F., \& Beheshti, Z. (2019). Combining hierarchical clustering approaches using the PCA method. Expert Systems with Applications, 137, 1-10. https://doi.org/10.1016/j. eswa.2019.06.064

Jimenez, P., \& Aquino, Fulvia. (2012). Propuesta de un modelo de competitividad de destinos turisticos. Estudios y perspectivas en turismo, 21 (4), 977-995. https://www.redalyc.org/articulo.oa?id=180724056010
Kubickova, M., \& Lee, S. H. (2018). Cuba today: An overview of tourism competitiveness. Tourism Planning \& Development, 15(3), 239-259. https://doi.org/10.108 $0 / 21568316.2017 .1410496$

Kumar, S., \& Dhir, A. (2020). Associations between travel and tourism competitiveness and culture. Journal of Destination Marketing \& Management, 18, https://doi. org/10.1016/j.jdmm.2020.100501

Li, Y., Liu, C. (2018). The role of problem identification and intellectual capital in the management of hoteIs' competitive advantage-an integrated framework. International Journal of Hospitality Management, 75 (2018), pp. 160-170. https://doi.org/10.1016/j. ijhm.2018.05.022

Mihalic, T., \& Aramberri, J. (2015). Myths of top tourism countries, tourism contribution and competitiveness. Tourism Review. Vol. 70 No. 4, pp. 276-288. https://doi. org/10.1108/TR-08-2014-0048

Mustafa, H., Omar, B., \& Mukhiar, S. N. S. (2020). Measuring destination competitiveness: an importance-performance analysis (IPA) of six top island destinations in South East Asia. Asia Pacific Journal of Tourism Research, 25(3), 223-243. https://doi.org/10.1080/109 41665.2019.1687534

Nazarian, A., Atkinson, P., \& Foroudi, P. (2017) Influence of national culture and balanced organizational culture on the hotel industry's performance. International Journal of Hospitality Management, 63 (2017), pp. 2232, https://doi.org/10.1016/j.ijhm.2017.01.003

Nazmfar, H., Eshghei, A., Alavi, S., \& Pourmoradian, S. (2019). Analysis of travel and tourism competitiveness index in middle-east countries. Asia Pacific Journal of Tourism Research, 24(6), 501-513. https://doi.org/10. 1080/10941665.2019.1590428

Pérez, V. E., Peral, F. J. B., González, M., Casas, F. M. G., Lozano-Oyola, M., García, F. P., \& Fernández, R. C. (2009). Evaluación de la sostenibilidad del turismo rural mediante indicadoressintéticos. Investigaciónoperacional,30(1),40-51.https:// rua.ua.es/dspace/bitstream/10045/92533/1/2016_Perles-Ribes_Canelobre.pdf 
Salinas, J., Serdeira, P., Martín, J., \& Rodriguez, J. (2020). Determinants of tourism destination competitiveness in the countries most visited by international tourists: Proposal of a synthetic index. Tourism Management Perspectives, 33. https://doi.org/10.1016/j. tmp.2019.100582

Singjai, K., Winata, I., \& Kummer, T. (2018). Green initiatives and their competitive advantage for the hotel industry in developing countries. International Journal of Hospitality Management, 75 (2018), pp. 131-143. https://doi.org/10.1016/j.ijhm.2018.03.007.

Shoval, N., \& Birenboim, A. ( 2019) Customization and augmentation of experiences through mo- bile technologies: A paradigm shift in the analysis of destination competitiveness. Tourism Economics, 25 (5) (2019), pp. 661-669. https://doi. org/10.1177/1354816618806428

Wang, X., \& Liu, D. (2020). The Coupling Coordination Relationship between Tourism Competitiveness and Economic Growth of Developing Countries. Sustainability, 12(6), 2350. https://doi.org/10.3390/ su12062350

Xia, H., Vu, H., Law, R., \& Li, G. (2019) Evaluation of hotel brand competitiveness based on hotel features ratings. International Journal of Hospitality Management. https://doi.org/10.1016/j.ijhm.2019.102366 